\title{
Scientific Approach Based on Problem-Based Learning of Marketing Subject to Improve Vocational Students' Critical Thinking Skill
}

\author{
Dewi Tinjung Sari ${ }^{1}$, Soetarno Joyoatmojo ${ }^{1}$, Dewi Kusuma Wardani ${ }^{1}$ \\ ${ }^{1}$ Economics Education, Sebelas Maret University, Surakarta, Indonesia
}

Corresponding e-mail: ${ }^{1}$ dewitinjungsari@gmail.com, ${ }^{2}$ strn_jo@yahoo.co.id, ${ }^{3}$ dewikw70@yahoo.com

\begin{abstract}
Students' learning effectiveness is influenced by learning environment consisting of learning model and approach. Vocational school learning in Surakarta is problematic since it is teacher-centered. The teachers teach the students by using conventional method so that the students tend to be passive especially in teaching retailing subject. Vocational schools learning should be focused on nurturing students to be active so that they have good problem-solving skill beneficial for their future career. Problem-based learning is a model that fosters students to find the solutions by doing reasoning based on the approach used in 2013 curriculum that is scientific approach. Scientific approach covers five stages as observing, questioning, gathering information, associating, and communicating. Problem-based learning can be developed and implemented as a $21 \mathrm{st}$ century learning model that encourages students to think critically by formulating, asking, analyzing, and providing solutions to the problems. By reviewing relevant literature, this article proposes recommendation that scientific approach-based problembased learning can be used to improve vocational school students' critical thinking skill in learning retailing subject.
\end{abstract}

\section{Keywords: critical thinking; problem-based learning; scientific approach}

\section{INTRODUCTION}

The qualified nation's next generation is characterized by the education evolution from time to time. Education is expected to produce qualified human resources in accordance with the quality of national education. The role of educators is critical to cultivate and encourage the students' motivation. An important component in improving the quality of education in Indonesia is mutual and supportive interaction between the teaching conducted by teachers and learning process done by students.

Curriculum shift from KTSP to 2013 curriculum is aimed at controlling the quality of education in order to realize the national education goal that is conducting education that fits the global demands. In 2013 curriculum scientific approach or science-based approach is implemented through several learning steps known as: observing, questioning, gathering information, associating, and communicating. One of the materials contained in 2013 curriculum for vocational school students majoring in marketing is retailing. Material on retailing subject is very complex. It contains theories on how to run a business by utilizing retailing principles. There are many theories that 
must be understood by students so that most students tend to memorize without understanding the material.

There are nine public vocational high schools (Sekolah Menengah Kejuruan Negeri - SMKN) in Surakarta with various departments. There are 3 of them that have marketing department, SMKN 1 Surakarta, SMKN 3 Surakarta and SMKN 6 Surakarta. The learning process is teacher-centered so that the students are less active. This learning process contrasts with the implementation of scientific approach in 2013 curriculum. The results of the interviews and pre-observations conducted on critical thinking skills aspects on XI grade students of public vocational high schools in Surakarta at marketing department while learning retailing subject illustrate that students almost never find a solution to the problem given by the teacher because they do not actively ask either their teacher or their friends. Students are not responsive to gather information related to the solutions of the problem and are unable to select the information. Discussions are rarely performed in learning. This makes students become passive and do not try to suggest solutions to the problem. The critical thinking skills data of XI grade students majoring in marketing analyzed based on critical thinking skill indicators are: SMKN 1 Surakarta 29.03\%, SMKN 3 Surakarta 32.26\%, and SMKN 6 Surakarta $33.33 \%$. It is still classified as very low. During learning, students do not pay attention to the teacher. When the teacher asked a question or proposed a problem; there are only one or two students who answered. When the teacher asked the students to do exercises, there were still some students who were just waited the answer, it was rarely seen that students discussed the solutions to the proposed problem. A person must improve the method of thinking (mindset) that corresponds to the current trends [11]. Someone has to change his/her thoughts so that good results will be achieved. Thus the student's critical thinking must be developed in learning.

Problem-based learning is a model that directs students to do sensible reasoning in understanding and making a complex selection on a problem solving process. This model is expected to be developed and applied as a model of learning in the $21 \mathrm{st}$ century. This model is an appropriate model to be used in the learning process in accordance with scientific approach. Problem-based learning is a learning model that is designed so that students gain important knowledge that helps them at solving problems and participating in the team.

Some theories that underline problem-based learning are: 1) learning theory proposed by Dewey, teachers should involve students in the learning process so that they can find solutions to a certain proposed problem; 2) constructivism theory proposed by Jean Piaget and Lev Vygotsky, they state that teaching learning process should be based on problem solving activity so that students can improve their understanding based on the learning experience outside and inside the class; and 3) learning theory proposed by Bruner which is discovery learning, students should use their knowledge to discover concepts and principles to observe, classify, measure, predict, and conclude through scientific observation [1]. Based on those theories, it is found that the advantage of problem-based learning is that it gives more opportunities for students to think, answer, and assist each other. Problem-based learning offers clear conclusion that helps students to solve a problem independently.

The learning process by using problem-based as one model of scientific approach includes several stages as: observing, questioning, gathering information, associating and communicating. The learning process with scientific approach is used to solve a problem or face a challenge that is needed in everyday life. The characteristics of 
problem-based learning are the use of real life problems as something to be learned by students to train and improve their critical thinking and problem solving skill as well as gain knowledge of key concepts. Here, the teacher's role is as a facilitator that provides guidance on a group or individual work. Students use skills to solve a problem in learning independently. Students are also able to compile, disclose, analyze and solve problems given by the teacher. Hence, the implementation of scientific approach-based problem based learning is a promising model to improve students' critical thinking skill.

\section{Critical Thinking Skill}

Retailing subject material is complex and correlates with how students should run a business so that it is necessary for students to think critically in order to solve real-life business problems. However, in fact, teaching learning processes conducted by teachers cannot nurture and improve students' critical thinking skill significantly. The learning process at the eleventh grade students majoring in marketing shows that the students hardly corporates high-order thinking skill in their learning. Most of the students tend to only memorize the learning material instead of understanding it. As a consequence, the students easily forget the material. A key component of critical thinking is how to develop the capacity to make an assessment [13]. With critical thinking, students will be more advanced because they can understand the issues in detail to make the educational process become more valuable and advanced, become the center of reasoning and cultivate a critical attitude [14]. A study that aims to improve students' critical thinking; teacher should conduct activities such as the use of concepts, principles, and procedures which are appropriate to the students. Hence, the teacher is able to produce a result and critical appraisal. In addition, critical thinking has important implications for the transfer of knowledge and application of problem-solving skills to new situations [12].

There are three aspects of critical thinking skills indicators [22]: the definition and clarification of the problem, the assessment and process of information related to the problem, the solution of problems or the conclusion. Aspects and sub-indicators of critical thinking skill are described as follows:

1. Definition and Clarification of Issues. This aspect has several sub indicators that include:

a. Identifying the central issues or points of concern.

b. Comparing the similarities and differences.

c. Create and formulate questions appropriately (critical question).

2. Assessing Information Related to the issue. This aspect has several sub indicators that include:

a. Students discover the causes of the problem occurrence.

b. Students are able to assess the impact or consequences.

c. Students are able to predict the further consequences of the impact of the incident.

3. Problem Solution / Conclusion. This aspect has several sub indicators that include:

a. Students are able to explain the problems and make simple conclusions.

b. Students design a simple solution.

c. Students are able to reflect the values or attitudes of the incident.

Indicators of critical thinking skills used in the study can be adjusted with the problems faced by the students in the learning process. 


\section{Problem-based Learning (PBL)}

Recommended model to overcome students' low critical thinking skill based on 2013 curriculum characteristics is scientific approach-based scientific model. Problembased learning is a teaching method that involves a student-centered learning through solving real problems [4]. This is a constructivist learning approach that focuses on students' skills in communicating and collaborating. It requires reflection from various points of view. There is a problem in learning that has not been resolved and there is no clear path or a clear procedure for the settlement. Thus, students conduct problem analysis on the context and apply deductive and inductive processes which are generalizable to understand the problems and find solutions to these problems. Problem-based learning is defined as learning that occurs through the process of how students solve problems and manage the real problem with the learning experiences [17]. PBL is learning to solve problems [1]. PBL is learning with comprehension, critical and creative thinking skills, problem-solving skills, communication, and use of knowledge significantly [15]. The characteristics of problem-based learning model are as follows: a) proposing a problem or question; b) linking with various problems disciplines; c) doing authentic investigation; d) generating and exhibiting product or work; and e) collaborating [7].

The implementation of problem-based learning model can support the students' critical thinking skills that include formulating, inquiring, analyzing and providing solutions to the problems that exist in the surrounding environment [2][12]. The use of PBL can help students to integrate reflective and critical thinking. Students can think critically in the modern world because of PBL model so that students can develop competence, problem-solving skill, knowledge, motivation, and reflective learning [5].

The implementation of the problem-based learning model or learning by problem consists of five main syntax of learning which starts from the teacher introduces a problem and ends with the presentation and analysis of students' work [7]. Such measures can be described as follows:

\section{PHASE-1.INTRODUCE STUDENTS ON THE ISSUE}

Teacher explains the purpose of learning, the logistics required, a phenomenon or a demonstration or a story to reproduce the problem, and motivates students to engage in selected problem.

\section{PHASE-2. ORGANIZE STUDENTS TO LEARN}

Teacher helps students to define and organize learning tasks related to the issue.

\section{PHASE-3. GUIDE BOTH INDIVIDUALS AND GROUPS INVESTIGATION}

Teacher encourages students to collect appropriate information and carry out experiments to get an explanation and solution to the problem. 


\section{PHASE-4. DEVELOP AND PRESENT THE WORK}

Teacher assists students in planning and preparing the appropriate work such as reports, videos, and models as well as helps them to share their work with friends.

\section{PHASE-5. ANALYZE AND EVALUATE THE PROCESS OF PROBLEM- SOLVING}

Teacher helps students to do reflection or evaluation on their investigations and the processes they use.

\section{Scientific Approach-based Learning}

In implementing 2013 curriculum in every school level, including vocational school; scientific approach is used. By implementing scientific approach, students are expected to think scientifically, objectively, logically, and critically towards the learning issues and problems. In thinking scientifically, further aspects of the student's cognitive ability are necessary to steer to the cognitive aspects of knowledge, thinking habits, character and values [3]. The concepts of scientific approach can affect the behavior, even the attitudes, of individuals to improve their thinking systematically [6]. Teachers should use scientific approach to teaching and learning activities to improve the students' ability [8]. The center of scientific activities at educational institutions is the effectiveness of the method or approach used [16]. Scientific learning is learning by using scientific methods involving the scientific process through two channels, reasoning and observing [18]. The scientific approach is effective to encourage and increase students' thinking skills and learning motivation.

The process of scientific approach is formulated into five categories. Formulate five steps of scientific approach in the learning process as follows [19]:

1. Observing. This aspect includes: reading, listening, and andwatching without or with a tool.

2. Questioning. Students ask questions about the information that is not understood from what is observed or question to gain additional information about what is observed (starting from factual questions to questions that are hypothetical).

3. Gathering information. Students do experiments, read sources other than textbooks, observe the objects or events, and interview the interviewees.

4. Associating. Students process the information collected either from the results of the experiment, observationor activities.

5. Communicating. Students deliver the observation and conclusion based on the spoken and written analysis, or other media.

\section{The Linkage between Problem-based Learning and Students' Critical Thinking Skill}

The generation living in the 21 st century must build thinking which follows current demands to think critically to solve various problems of modern society [11]. Thus, students are required to build critical thinking in the learning process that would affect 
their learning outcomes which include a written test, performance, and products beneficial to the surrounding environment. Low critical thinking skill can be overcome with the use of problem-based learning as one model of scientific approach. This model directly involves students in learning. Learning will be easier if the teacher implements problem-based learning. This happens since through discussion, students can understand the concept of learning materials briefly. Thus, students will broadly understand what is happening now in the community.

Problem-based learning (PBL) is an approach that encourages active learning through the creation of an environment. In PBL, the task is designed with the influence of socio-constructivist learning theory [10]. This learning method helps students to be independent, so that they can continue to learn and to solve problems throughout their lives. The technique is student-centered learning. There are four objectives of problembased learning as follows:

1. Broaden and deepen knowledge;

2. Facilitate clinical / professional manner of reasoning;

3. Develop independent learning skills;

4. Promote teamwork skills (especially communication, self-awareness and in recognition of each other) [17].

The purpose of problem-based learning is to stimulate critical thinking of students; improve professional competence; enhance problem-solving skills; improve collaboration and decision-making skills in a new problem situation; and achieve skills that encourage lifelong learning, self-evaluation, and adaptation [2]. Problem-based learning instruction shows that this type of learning was built by the students who were given a problem. Students are involved in the settlement of the problem and they have to conduct an investigation with their partners (discussion) to identify problems and find solutions [9]. Problem-based learning as one model of scientific approach emphasizes five steps including observing, questioning, gathering information, associating, and communicating. Problem-based learning as a model of learning has some characteristics as: a) it is realistic to the students' real-life, b) the concept taught is suitable with the students' needs, c) it improves the ability of students to investigate problems, d) it enhances students' learning memory, and e) it increases the ability of students to solve and resolve a problem [21].

By learning with problem-based learning, students can improve their critical thinking through problem solving. Students' social skills as well as social environment are also increased [20]. Students' critical thinking skill will increase and students are able to find solutions to problems in each group. Good teamwork in problem solving during problem-based learning will affect the student's activity to solve the problem so that the material can be understood and studied by each member of the group. The process of discussion motivates students to have a high curiosity. Students also will not hesitate to ask the group members and teachers about things they do not understand. All students in problem-based learning shall cooperate and understand the problems. As the students' critical thinking improves, their problem-solving skill will also improve. 


\section{CONCLUSION}

Problem-based learning is a model that utilizes problem as a learning starting point is believed to be able to improve vocational students' critical thinking skill. Problembased learning provides an opportunity for students to conduct analytical work started on finding a problem, analyze a problem, and solve a problem. This model is one of the recommended models for the implementation of 2013 curriculum with scientific-based approach. The steps of scientific approach are observing, questioning, gathering information, associating, and communicating. Those steps are suitable when it is collaborated with the syntax of problem-based learning model stages including: students 1) orient the problem, 2) organize the study, 3) do individual or group investigation, 4) develop and present the work, and 5) analyze and evaluate the problem solving process. Based on the study of the literatures; it can be conclude that the collaboration of problem-based learning and scientific approach can make the students to be more active in learning so that it can promote and enhance their critical thinking skill in solving the learning problem. Hence, students will comprehend the retailing subject learning material more easily since they are accustomed to solve real-life problems.

\section{REFERENCES}

[1] Arends, R. I. 2012. Learning to Teach. New York: McGraw-Hill.

[2] Asyari, M., Al Muhdhar, M. H. I., Susilo, H., \& Ibrohim. (2016). Improving Critical Thinking Skills Through the Integration of Problem Based Learning and Group Investigation. International Journal for Lesson and Learning Studies, 5 (1), 36-44.

[3] Choi, K., Lee, H., Shin, N., Kim, S-W. \& Krajcik, J. (2011). Re-Conceptualization of Scientific Literacy in South Korea for the 21st Century. Journal of Research in Science Teaching, 48(6), 670697.

[4] Etherington, B. M. 2011. Investigative Primary Science: A Problem-based Learning Approach. Australian Journal of Teacher Education, 36 (9), 35-57.

[5] Gholami, M., Moghadam, P, K., Mohammadipoor, F., Tarahi, M, J., Sak, M., Toulabi, T. et al. 2016. Comparing The Effect of Problem Based Learning and The Tarditional Lecture Method on Critical Thinking Skills and Metacognitive Awareness in Nursing Students in a Critical Care Nuring Course. Nurse Education Today, 45 (1), 16-21.

[6] Haas, A. 2011. On a Physical Scientific Approach to Transpersonal Psychology. International Journal of Transpersonal Studies, 30, (1/2), 69-81.

[7] Hosnan. 2014. Pendekatan Saintifik dan Kontekstual dalam Pembelajaran Abad 21: Kunci Sukses Implementasi Kurikulum 2013. Bogor: Penerbit Ghalia Indonesia.

[8] In'am, A., \& Hajar, S. 2017. Learning Geometry through Discovery Learning Using a Scientific Approach. International Journal of Instruction, 10 (1), 55-70.

[9] Jiriyasin, T. 2014. Enlivening EFL Discussion Calssrooms with a Problem-Based Learning Approach. Pasaa, 47 (1), 129-146.

[10] Karami, M., Karami, Z., \& Attaran, M. 2013. Integrating Problem Based Larning with ICT for Developing Trainee Teachers' content Konowledge and Teaching Skill. International Journal of Education and Development using Information and Communication Technology (IJEDICT), 9 (1), 36-49.

[11] Lin, Y. M., \& Lee, P. C. 2013. The Practice of Business's Teacher Teaching: Perspective from Critical Thinking.International Journal of Business and Commerce, 2 (6), 52-58. 
[12] Masek, A., \& Yamin, S. 2011. The Effect of Problem Based Learning on Critical Thinking Ability: A Theoretical and Empirical Review. International Review of Social Sciences and Humanities, 2 (1), 215-221.

[13] Orgad, M. S., \& Spiller, D. 2014. Critical Thinkers and Capable Practitioners Preparing Public Relations Students for The 21st Century. Journal of Communication Management, 18 (3), 210-221.

[14] Pinto, L., McDonough, G. P., \& Bailin, S. 2011. High SchoolPhilosophyTeachers use of Textbooks: CriticalThinking or Teaching to the Text. Journal of Curriculum and Instruction (JoCI), 5 (2), 45-78.

[15] Rahyubi, H. (2012). Teori-Teori Belajar dan Aplikasi Pembelajaran Motorik: Deskripsi dan Tinjauan Kritis. Bandung: Nusa Media.

[16] Rodionov, N. 2011. Training Scientific and Engineering Specialists at Te Scientific Educational Centre "The Center of Radiation Resitive Diamond Nanoelectronics and Innovation" of SRC RF Triniti. Journal of International Scientific Publication, 10 (2), 33-41.

[17] Sadlo, G. 2014. Using problem-based learning during student placements to embed theory in practice. PBLH: The Higher Education Academy, 2 (1), 6-19.

[18] Said, I. M., Eddy, S., \& Sugandi, M. 2016. The Scientific Approach-Based Cooperative Learning Tool for Vocational Students Vocation Program of Autotronic (Automotive Electronic) Engineering. Journal of Research \& Method in Education (IOSR-JRME), 6 (3), 67-73.

[19] Supasorn, S., \& Waengchin, S. 2014. Development of Grade 8 students' learning achievement on chemical reaction by using scientific investigation learning activities. Procedia-Social and Behavioral Sciences, 116(1),744-749.

[20] Tlhapane, S. M., \& Simelane, S. 2010. Technology-Enhanced Problem-Based Learning Methodology In Geographically Dispersed Learners of Tshwane University of Technology. Knowledge Management \& E-Learning: An International Journal, 2 (1),68-83.

[21] Trianto. 2010. Model Pembelajaran Terpadu. Jakarta: BumiAksara.

[22] Tukan, D. D. (2009). Peningkatan Kemampuan Berpikir Kritis Siswa dengan Model TASC (Thinking Actively in a Social Context) Pada Pembelajaran IPS. Jurnal Pendidikan, 1 (1), 15-29. 